\title{
Effectiveness of Indonesian National Police Chief Regulation Number 8 of 2011 Regarding Fiduciary Execution Protection
}

\author{
Dwi Fani Arsikasindi*; Burhanudin Harahap \\ Faculty of Law, Universitas Sebelas Maret, Indonesia \\ Email: dwifani44@gmail.com
}

http://dx.doi.org/10.18415/ijmmu.v5i4.422

\begin{abstract}
The present study analyzed the implementation of fiduciary execution protection particularly in Surakarta and Karanganyar Regency as it is mentioned in Indonesian National Police Chief Regulation number 8 of 2011 regarding Fiduciary Execution Protection (Hereinafter referred to as Peraturan Kapolri nomor 8 Tahun 2011). This study is classified as a descriptive-empirical study. This study took place in Karanganyar City Police, Surakarta District Court, and Karanganyar District Court. This study found that sociologically, Indonesian National Police Chief number 8 of 2011 regarding Fiduciary Execution Protection in Surakarta had been effective based on the expert observation. However, there was incongruence between the statement in the regulation and the field fact so that the regulation became less effective particularly in its implementation in Surakarta and Karanganyar Regency. It needed improvement so that the implementation of fiduciary execution protection can be in accordance with the Indonesian National Police Chief Regulation number 8 of 2011 regarding Fiduciary Execution Protection. So, it can be clearly stated that the Indonesian National Police Chief regulation number 8 of 2011 regarding Fiduciary Execution Protection and its implementation effectively prevails.
\end{abstract}

Keywords: Effectiveness; Indonesian National Police Chief Regulation; Protection; Execution; Fiduciary Security

\section{Introduction}

Article 1 number 1 of Law no. 42 of 1999 on Fiduciary Security (hereinafter referred to as Law on Fiduciary) states that: Fiduciary is a transfer of ownership of an object on trust with the provision that transferred ownership of the object remains in the control of the owner of the object.

Based on the provision in that article, a fiduciary can be defined as a transfer of ownership based on the debtor' trust to the creditor for a guarantee of a debt, in which the debtor holds the ownership of the object. In Bahasa Indonesia, it is called as "penyerahan hak milik secara kepercayaan". ${ }^{1}$

\footnotetext{
${ }^{1}$ Munir Fuady. (2013). Hukum Jaminan Utang. Erlangga, Jakarta, p. 101.
} 
Law on Fiduciary does not use the term "default", instead it uses the term "breach the contract" as it is regulated in article 15 paragraph (3) which read: If the debtor breaches the contract, the fiduciary receiver has the right to sell the the object of fiduciary on his own behalf. However, in praxis, although it is not stated within Fiduciary Law, the creditor can take the procedure of normal execution through a regular lawsuit to the Court. $^{2}$

The fiduciary provider is obliged to hands the object which becomes the fiduciary security object in order to perform the execution of fiduciary security. It is regulated in article 30 of Fiduciary law which states that: Fiduciary giver shall deliver the object of Fiduciary for Fiduciary execution.

If the Fiduciary Provider does not deliver the object of Fiduciary for executed at execution time, the Fiduciary receiver is entitled to take the item that is the object of Fiduciary and if necessary to ask for the assistance of the authorities. This is regulated in the elucidation of article 30 of Fiduciary Law.

Regulation on the fiduciary security does not explicitly regulate who are authorized to assist in fiduciary execution. However, in fact, the creditor often asks for assistance to the police in performing the fiduciary execution.

Based on the description above, this study will discuss the effectiveness of the implementation of Indonesian National Police Chief Regulation number 8 of 2011 regarding Fiduciary Execution Protection.

\section{Methodology}

The present study was an empirical study (non-doctrinal), It studies law in reality in the society. This study covers a study on the legal identification (unwritten law) and the effectiveness of the law. ${ }^{3}$ The nature of this study is descriptive. Descriptive study is research that aims to provide accurate data regarding human, circumstances, or other phenomena. ${ }^{4}$

The source of the study was classified into the data obtained directly from society and those obtained from the literature review. The data obtained from the society is called as primary data, while the data obtained from the literature study is called as secondary data. ${ }^{5}$

The data analysis technique of this study was the interactive model of qualitative analysis. It was done through interaction on its component and data collection process in the form of cycle. ${ }^{6}$

\section{Discussion}

\section{A. Duties of Indonesian National Police}

Indonesian National Police is the state instrument that works and takes a role in maintaining the security and the order of society, legal enforcement, protection, and service to the society. ${ }^{7}$

In carrying out its main duty, Indonesian National police is in charge to: ${ }^{8}$

\footnotetext{
${ }^{2}$ Munir Fuady. (2000). Jaminan Fidusia, Citra Aditya, Bandung, p. 62.

${ }^{3}$ Mukti Fajar. (2010). Dualisme Penelitian Hukum Normatif\&Empiris, Pustaka Pelajar, Yogyakarta, p. 153.

${ }^{4}$ Soerjono Soekanto. (2010). Pengantar Penelitian Hukum, Universitas Indonesia Press, Jakarta, p. 5-6.

${ }^{5}$ Ibid, p.51.

${ }^{6}$ HB. Sutopo. (2006). Metodelogi Penelitian Kualitatif, Universitas Sebelas Maret Press, Surakarta, p.91-96.

${ }^{7}$ Polri, Kepolisian Negara Republik Indonesia, Visi dan Misi,www.polri.go.id, accessed Monday, 02 October 2017 at 10.00 WIB.

${ }^{8}$ Wikipedia Ensiklopedia Bebas, Kepolisian Negara Republik Indonesia, https://id.wikipedia.org/wiki /Kepolisian_Negara_Republik_Indonesia, accessed Tuesday, 17 July 2018, at 19.00 WIB.
} 
1. perform control, guard, escort, and patrol of the community and government activities as needed;

2. supply all activities to ensure the safety and smoothness of traffic on the road;

3. develop community participation, legal awareness, as well as conformity on law and regulatory legislation;

4. participate in the development of national law;

5. implement order and ensure public safety;

6. implement co-ordination, supervision, and technical guidance to the investigators, civil servants/ authorities, and the forms of private security;

7. implement the investigation against all criminal acts in accordance with the criminal procedure law and other legislation;

8. implement identification such as police medical operations, psychology, and police forensic laboratory for the interests of the police duties;

9. Protect the life, property, society, and the environment safety from disturbances and/or disaster, including providing aid and relief to uphold human rights;

10. serve interests of citizens for a while before the agency and/or authorities handle it;

11.give services to the public in accordance with the interests of the police task environment;

12.implement other duties in accordance with the legislation, which in practice regulated by Government Regulation;

\section{B. Authorities of Indonesian Nasional Police}

In performing its duties, Indonesian National police, in general, is authorized to: ${ }^{9}$

1. Receive reports and/ or complaints;

2. help resolve community disputes that may interfere with the public order;

3. Prevent and overcome the growth of social disease;

4. supervising the flow that can lead to the dismemberment or threaten the unity of the nation;

5. publicising police regulations within the scope of police administrative authority;

6. implementing special examination as part of the police identification;

7. respond first and rapid action to a scene;

8. Take the identity, fingerprints, and photograph of a person for identification purposes;

${ }^{9}$ Ibid, accessed Tuesday 17 July 2018 at 19.30 WIB. 
9. looking for information and evidence;

10.organizing the National Crime Information Center;

11.issuing license and/ or certificate that is required to serve the community;

12. Give security assistance in the trial and execution of court decisions, the activities of other agencies, as well as community activities; and

13.to Receive, secure, and keep founded lost items for a while until further identification.

\section{The Effectiveness of Indonesian National Police Chief Regulation no. 8 of 2011 regarding Fiduciary Execution Protection}

\section{Norm Effectiveness}

One of the examples of case occured in Karanganyar regency was executory attacment between PT. The initial agreement was the loan of PT. $X$ in the form of money by the amount of Rp. 4.500.000.000 (Four Billion and Five hundred Million rupiahs) to Cooperative Y in 2007. The agreement was made and implemented in Surakarta with PT. X' sewing machines in Karanganyar as the object of fiduciary security. For this case, an application was filed to Surakarta Court District which was then delegated to Karanganyar Court District, so that the executory attachment was performed by Karanganyar Court District which were then re-delegated to Surakarta Court District who issued the initial provision. From this case, it was initially refusal by Surakarta Police since the object of fiduciary security was not located in Surakarta although the agreement was made in Surakarta. It proves that Police can only perform protection under the police duty territories.

Based on the findings of the study in the field regarding the fiduciary execution protection, Indonesian National Police Chief Regulation no. 8/2011 regarding Fiduciary Execution Protection had been effectively implemented in field. However, normatively reviewed, there is incongruence between Indonesian National Police Chief Regulation no. 8/2011 in aricle 20 item d and its implementation. Article 20 item d states that: if the respondent holds a legitimate payment proof, the Personnel of Indonesian national police shall:

1. Postpone or stop the execution;

2. Bring and hand the officer appointed by the applicant to the investigator for further investigation and;

3. Bring the applicant and the respondent to the nearest police office for further handling.

In the study conducted by the researcher both in District Court and Departmental Police, the police authority is limited to protect, so the statement stated in article 20 item d was not in accordance with the praxis implementation. If the respondent holds legal payment proof, it shall be solved before the court and not the part of police investigator or other police member authority. ${ }^{10}$

To what extent the court rulings may affect a law is an essential issue in empirical point of view. The judge' ruling cannot be seen merely from juridical-formal aspect, instead, it shall be seen as an autonomous thing based on non-legal factors. ${ }^{11}$

\footnotetext{
${ }^{10}$ Interview with Jaka Tavip.S. (2018). Court Bailiff in Surakarta District Court on 17 July 2018.

${ }^{11}$ Achamd Ali dan Wiwie Heryani. (2012). Menjelajahi Kajian Empiris Terhadap Hukum, Kencana, Jakarta, p. 150.
} 
If it is reviewed from the norm effectiveness, Indonesian National Police Chief Regulation no. 8 of 2011 has been implemented in line with the provision stated within the regulation. There was an incongruence on its field implementation, however as long as it does not occur and is not questioned, the Indonesian National Police Chief Regulation no. 8 of 2011 works effectively.

\section{Goal Effectiveness}

Indonesian National Police is a state instrument that work and take a role in maintaining the security and the order of society, legal enforcement, protection, and service to the society. Indonesian National Police is also authorized to provide protection in the execution of court ruling or fiduciary execution, other institutional activity and community events.

Fiduciary execution holds a binding legal force, so that it needs protection from Indonesian National Police.

Police is the most authorized party in providing security assistance to perform fiduciary execution. Police authority in securing fiduciary execution is aimed at establishing a safe, orderly, expeditious fiduciary execution and protecting the security of the Fiduciary receiver, Fiduciary provider, and/or community from the actions that may lead to property and security loss. It means that the scope of police in protecting fiduciary execution is in the scope of protecting the security of both parties (Fiduciary provider and receiver) as well as society in general from actions, behaviors, and things that damage property and security.As it is stated in article 2 of Indonesian National Police Chief Regulation number 8 of 2011.

After the issuance of Indonesian National Police Chief Regulation number 8 of 2011 regarding Fiduciary Execution Protection, creditors find it very helpful since Police is authorized to perform legal action which cannot be done by other parties if the debtors commit refusal or resistance in during the execution.

Essentially, fiduciary execution always asks protection from the authorized apparatus, and can be performed without court rulings. The stages of request for execution is begun with the execution application, then there will be a provision of aanmaning/ warning. After that, the judge will call upon the parties especially the respondent to be warned. If the judge call upon the respondent for warning does not result in a solution, the applicant will increase the status of request for execution. ${ }^{12}$

Aanmaning is a warning against the defendant so that the defendant perform the court rulings in a civil case which have already held permanent legal force, voluntarily within 8 days. If the debtor does not obey the summons, public summon through mass media will be performed. Only then, the execution on the object as fiduciary security can be performed. So, the execution cannot be performed immediately.

Essentially, fiduciary security is flexible, although the regulation gives warning for eight days, in praxis it can be months and be immediately revoked for the respondent pay off the debts. So, such aanmaning is considered as mediation procedure, different from the case implemented in accordance with its stages. In other words, the applicant shall be pro-active with his/her application. ${ }^{13}$

However, before execution request, executory attachment is possibly requested. If the status becomes execution request, the court will hold coordination meeting with the authority who is usually consisted of Subdistrict Leader Forum (Muspika), District Military Command (Kodim), Koramil

\footnotetext{
${ }^{12}$ Interview with Jaka Tavip.S, Court Bailiff in Surakarta District Court on 17 July 2018.

${ }^{13}$ Interviews with Mrs. Melanie, S.H., M.M, Staff of Civil Clerk of Surakarta District Court on 04 June 2018.
} 
(Regional Military Command), Denpom (Military Police Detachment) and Polri (Indonesian National Police) as well as discussing the tricks and methods in facing the debtors or the respondent during the fiduciary execution.

The role of police in providing the protection for fiduciary execution is limited in providing the protection towards the execution. Execution protection provided by Police for every execution request filed to the Court. Almost all execution protected by Police, especially in Surakarta and Karanganyar regency, run smoothly. However, there was a resistance from the respondent so that the execution was hampered. As long as it is still under control and able to be secured, the execution process still runs, but if the apparatus or police is overwhelmed and cannot handle it, the executioner reports it firstly to the court chairperson, then the police can issue a statement of inability to handle so that the execution is temporarily postponed. ${ }^{14}$ The respondent resistance can be in the form of Civil Society Organization (LSM) aid and even the respondent can mobilize the local community to resist the execution.

If it is reviewed from the Goals effectiveness, Indonesian National Police Chief Regulation no. 8 of 2011 has been implemented in line with the provision stated within the provision. Police as the state instrument provides fiduciary execution protection as its duties and authority as a protector.

\section{Theory of Chambliss and Seidman}

Correlated to the theory of Chamblis and Seidman who states that the work on law is began by the the making of law, it is the reflection of the social model. Accodrding to Chambliss and Seidman, social can be classified into two models namely s. ${ }^{15}$

\section{Value Consensus Model}

The making of law is to determine the values prevailing among the society. The making of law is the reclection of values agreed by the society.

\section{Social Conflict Model}

The making of law is seen as the process of power competition, a state is a weapon held by the powerful group of community. Although there are values discord, the state can still stand as value-netral party.

According to this theory, the making of law and its implementation cannot be separated from the effect of personal and social power. Indonesian National Chief Regulation no. 8/2011 on the Fiduciary Execution protection has been in accordance with the values prevailing among the community. Police as the state instrument perform a protection in neutral, they perform protection for each party during the execution.

\section{Conclusion}

A regulation or a law is not considered ineffective if the most of member of the community do not obey it. However, when most of the community member seem to adhere to such law, the quality and

\footnotetext{
${ }^{14}$ Interview with Mr. Iptu Herawan, the chief of Cyber Crime of criminal investigation of Departmental Police of Karanganyar on 04 June 2018.

${ }^{15}$ RobertB. Seidman \& William J. Chambles, Law, Order, and Power, Printed in United States of America, Pubhlised Stimulant Costly in Canada Library of Congress Catalog Card Nomor. 78-111948.
} 
the quantity of effectiveness of such regulation or law is still questionable for the effectiveness is not merely measured by whether or not a regulation has been obeyed.

Indonesian National Chief Regulation no. 8/2011 on the Fiduciary Execution protection has been effectively implemented. It is performed under the procedure and the regulation in force. However, the statement of article 20 item d of Indonesian National Police Chief Regulation no 8/2011 was not in accordance with the praxis in the field. If the respondent holds legitimate payment proof, it shall be solved before the court and not the part of police investigator or other police member authority. Although it did not occur in the fiduciary execution in Surakarta and Karanganyar regency, still, it did not appear in accordance with the duties and obligations of Police in protecting fiduciary execution. In other words, normatively, Indonesian National Police Chief Regulation number 8 of 2011 is less effective in the formulation. However, it is sociologically effective in its implementation in community' life.

\section{Suggestion}

Fiduciary execution will be better if it is performed in accordance with the Indonesian National Police Chief regulation number 8 of 2011 regarding Fiduciary Execution Protection and does not contradict with other regulatory legislation. In general, Indonesian National Police Chief Regulation number 8 of 2011 has been effectively implemented. However, it needs improvement to minimize hindrance during fiduciary execution.

\section{References}

Achamd Ali dan Wiwie Heryani. (2012). Menjelajahi Kajian Empiris Terhadap Hukum, Kencana, Jakarta.

HB. Sutopo. (2006). Metodelogi Penelitian Kualitatif, Universitas Sebelas Maret Press, Surakarta.

Munir Fuady. (2000). Jaminan Fidusia, Citra Aditya, Bandung. . (2013). Hukum Jaminan Utang, Erlangga, Jakarta.

Mukti Fajar. (2010). Dualisme Penelitian Hukum Normatif\&Empiris, Pustaka Pelajar, Yogyakarta. Peraturan Kepala Kepolisian negara Republik Indonesia Nomor 8 Tahun 2011 Tentang Pengamanan Eksekusi Jaminan Fidusia.

Polri, Kepolisian Negara Republik Indonesia, Visi dan Misi,www.polri.go.id, accessed Monday, 02 October 2017 at $10.00 \mathrm{WIB}$.

Putera Gembala, Antar Berita Pengertian Efektivitas dan Efisiensi, http://antarberita.blogspot.co.id, accessed Thursday, 12 April 2018, at 8.00 WIB.

RobertB. Seidman \& William J. Chambles, Law, Order, and Power, Printed in United States of America, Pubhlised Stimulant Costly in Canada Library of Congress Catalog Card Nomor. 78-111948.

Soerjono Soekanto. (2010). Pengantar Penelitian Hukum, Universitas Indonesia Press, Jakarta. 
Undang-Undang Republik Indonesia Nomor 42 Tahun 1999 tentang Jaminan Fidusia Wikipedia Ensiklopedia Bebas, Kepolisian Negara Republik Indonesia, https://id.wikipedia.org/wiki /Kepolisian_Negara_Republik_Indonesia, accessed Tuesday, 17 July 2018, at 19.00 WIB.

\section{Copyrights}

Copyright for this article is retained by the author(s), with first publication rights granted to the journal.

This is an open-access article distributed under the terms and conditions of the Creative Commons Attribution license (http://creativecommons.org/licenses/by/4.0/). 